\title{
Brand Strategy in Higher Education; Before and During Pandemic COVID-19
}

\author{
Siti Ma'rifatul Hasanah", , Maryam Faizah², Maslihatul Bisriyah ${ }^{3}$ \\ 1,2,3 Universitas Islam Negeri Maulana Malik Ibrahim Malang, Indonesia \\ *Corresponding author. Email: riefah.hlc@gmail.com
}

\begin{abstract}
The Covid-19 pandemic which began to spread at the end of 2019 had an impact on many aspects of life. Educational institutions are faced with new challenges that force leaders to change and take strategic steps, including in managing the university brand. This study focuses on two things, namely the branding strategy that is implemented before and during the pandemic. Using a qualitative approach, this study resulted in two discussions, namely: 1) the branding strategy implemented at UIN Maulana Malik Ibrahim Malang before the pandemic began with an analysis of the segments to be served, gradually UIN Malang determined the national, regional and international levels. Then proceed with building campus positioning, strengthening differentiation and communicating well to stakeholders. 2). The university's branding strategy during the pandemic begins by analyzing the needs of primary stakeholders (students) and the urgent matters that should be given to them. Trying to communicate the positioning of the campus, the university values that must be conveyed to students, strengthen and be more creative in creating differentiation, especially in the digital field. Doing creative digital promotions. Offers convenience, modern and attractive digitization, but remains strong in the university's positioning.
\end{abstract}

Keywords: Brand Strategy, Higher Education, Covid-19 Pandemic

\section{INTRODUCTION}

The Corona Virus Disease (COVID)-19 pandemic, which began to spread at the end of 2019, has an impact on many aspects of life. The world is changing rapidly including the management of educational institutions. Educational institutions faced new challenges that force leaders to change and take strategic steps. Then, what about the big brands from educational institutions? How can they survive and win the hearts of stakeholders?

Brand is a very valuable intangible asset of an organization [1]. Educational institutions, as non-profit organizations, have begun to use branding strategies in their management. The brand must be managed and maintained with the utmost care, consistency, and appropriateness as an essential element. If a brand is not managed properly, it cannot have long-term success. Managing a brand needs to adapt frequently, along with technological advances, the pace of change and sometimes against consistency [2].
The COVID-19 pandemic demands changes in many ways. The use of rapid learning technology and all online activities test how strong a brand can survive. Stakeholders need new things that have not been provided by the organization before. A brand revolution seemed like it was happening. Stakeholders need not only to be heard, but also to fulfil everything they want.

As one of Islamic higher education, UIN Maulana Malik Ibrahim Malang pioneered some of the flagship programs in Islamic universities and became a pilot for those programs. This study will discuss how the management of uin maulana malik ibrahim malang brand before and during the pandemic period. The focus of this problem is on the branding strategy implemented at uin maulana malik ibrahim malang, before and during the covid-19 pandemic.

This study will address the following questions: (1) What is the branding strategy of UIN Maulana Malik Ibrahim Malang before the pandemic? (2) What is the branding strategy of UIN Maulana Malik Ibrahim 
Malang during the pandemic? The purposes of this study are: (1) Describe the branding strategy of UIN Maulana Malik Ibrahim Malang before the pandemic and (2) Describe and analyze the branding strategy of UIN Maulana Malik Ibrahim Malang during the pandemic.

\section{LITERATURE REVIEW}

\subsection{Corona Virus 19}

The Corona virus 19 pandemic is the spread of the corona virus around the world. This virus was named SARS Cov-2. It first spread in Wuhan City, Hubei Province, China, at the end of 2019, to be precise December 1, 2019. And on March 11, 2020 it was designated as a pandemic by the WHO [3].

This virus can be transmitted through respiratory droplets, either when coughing or in normal condition. In addition, this virus can also be transmitted by touching objects contaminated with the virus. Spread can be through people with symptoms or without symptoms. Symptoms of this disease include cough, fever, and shortness of breath. There is no cure for this disease so far. The prevention is carried out by washing hands, wearing masks, keeping a distance from other people, increasing body immunity, as well as monitoring and independent isolation for those who are infected.

Several efforts to prevent the spread of the virus are carried out through quarantine, travel restrictions, postponement of events, avoiding crowds, and closing access to public facilities, including schools. More than 124 countries have closed schools and universities to prevent the spread of the virus. Learning is carried out online (in a network) and everyone must begin to adapt to the use of information technology in learning until uncertain time.

\subsection{Branding Strategy in the Digital Age}

The World Wide Web (WWW) was created in 1989 in a European laboratory for elements of physics through the introduction of "hypertex" links that allow humans to access a wide range of information. The use of the internet and the web has increasingly dominated when e-commerce began to emerge, the internet began to be used for business applications. And now, with the emergence of the COVID-19, educational services both teaching and administrative services are all carried out through the internet. The internet changes the human ability to interact in economic, social, political, cultural, and educational terms [2].

The rapid development of the internet has influenced brand management in profit and non-profit organizations. During this pandemic, all educational institutions began to adapt to online activities, including starting to manage their institutional brands [4]. Of course, there are some differences in brand management before and during a pandemic [5]. As for the theory of branding strategy, in general, it has the following steps:

\subsubsection{Segmentation}

Segmentation is an element of strategic marketing that must be done by an organization properly. Segmentation is also an important part of the strategy to build an organization's brand image. To operate effectively, an organization first needs to define its mission or "reason for being". In this mission, the organization needs to understand "what is the organization engaged in?". After determining the mission and the market, it is necessary to divide the market into smaller segments based on similar characteristics of stakeholder behavior, and then determine which segments will be served [6][7].

\subsubsection{Targeting (Allocate your resources effectively)}

In general, targeting is defined as the process of selecting the market that the organization will target in offering products or services. Another definition states that targeting is a strategy to allocate limited resources effectively to the right target market through the evaluation process and determine which segments will be served, so that the organization must review the potential of its target market (target market) in the future [8].

\subsubsection{Positioning (Lead your customer credibly)}

Positioning is a promise. An action to design the offer and image of the organization so that the organization can be in a competitive position that is meaningful and in the minds of stakeholders [9]. Another definition states that positioning is a process to place the organization in the minds of stakeholders. This definition means that the organization must have credibility so that the organization's positioning can easily stick in the minds of stakeholders [8][10].

\subsubsection{Differentiation}

Differentiation in general means how to create a different organization compared to other competitors. Philip Kotler [6] defines differentiation as differentiating an organization's market offerings to create superior stakeholder value. Meanwhile, Hermawan Kartajaya [10] defines differentiation as the process of integrating the content, context, and infrastructure of what is offered to stakeholders. The process of integrating is carried out through the process of creating a unique offer by concentrating on 
dimensions, content (what to offer), context (how to offer), and infrastructure (enabler) [11].

\subsubsection{Brand}

An organization should think of its brand as: (1) a product, (2) an organization, (3) a person, and (4) a symbol. These perspectives vary, but the aim is to clarify, enrich, and differentiate the brand identity. Brand identity can provide direction, purpose, and meaning of the brand itself. The brand association represents what an organization promises to its stakeholders [12].

As for managing brands in the digital era like now, there are several things to focus on, including [2]:

\section{a. Consistency Vs Change.}

One of the links between brands and technology is the demand for consistency of values that must be upheld by the brand. On the other hand, changes to keep up with technological developments are urgent to do.

\section{b. Focus on features}

Technology makes organizations focus more on features than on their brands. Although in fact feature development does not directly affect brand selection. So that building a brand requires more attention.

\section{c. Focus on quality}

The use of technology often makes brand managers pay less attention to quality. Some organizations find it difficult to focus on two things at once, namely the quality and adaptability of technology. Technology is a means, a medium for survival, survival, and balance. Meanwhile, quality is the core thing that we offer to stakeholders.

\section{METHOD}

This study uses a qualitative method in which the researcher collects data by interacting with people faceto-face at the research site [13]. Qualitative research is a type of research where the findings are not obtained through statistical procedures [14]. This research was conducted at UIN Maulana Malik Ibrahim Malang, which is located on Gajayana Street 50 Malang.

The data in this research are real information or materials that can be used as evidence and the basic material for the study. Meanwhile, the data source is the subject where the data is obtained. Sources of data in this study can be divided into two, namely humans and non-humans. Human data sources function as subjects or key informants. Meanwhile, non-human data sources are documents that are relevant to the focus of the research, such as pictures, photos, meeting notes or writings that are related to the research focus. In this study, there are two sources of data, namely primary data sources and secondary data sources [15]. The following is an explanation regarding the two data sources[16]:

1. Primary sources, namely data obtained directly from the source, for example informants, social sites or observed events.

2. Secondary data sources are data or information obtained from other sources or have been processed by other parties, such as documents.

\section{RESULT AND DISCUSSION}

\subsection{Branding strategy of UIN Maulana Malik Ibrahim Malang before the pandemic}

The strategy used by UIN Maulana Malik Ibrahim Malang before the pandemic was to realize the university's vision and mission. Sociologically, a civilization is great because of the size of a vision. Likewise, with the vision of UIN Maulana Malik Ibrahim Malang. The big vision of UIN Maliki Malang is to become a superior, trusted, competitive and internationally reputable university. This campus has a noble aspiration to become a center of excellence and Islamic civilization. To achieve this lofty ideal, the university has a unique and specially designed special education model in accordance with these lofty ideals [17].

The brand building strategy that has been carried out at UIN Maulana Malik Ibrahim Malang includes determining campus segmentation. Namely the target of prospective students who are the targets of UIN students. This segmentation includes expansion, starting from the local and national levels. Then expanded to regional and international levels. Until now, there have been recorded foreign students from 22 countries. After segmentation, UIN Malang determines targeting. Namely after determining the target market of UIN Malang, then starting to carry out promotions aimed specifically at the target market. Targeting is more about allocating resources to attract prospective students.

The segmentation and targeting program do not only map the breadth of the target market and allocates campus resources to create programs that attract prospective students. But this is more interpreted as da'wah, a syiar to introduce Islam as a religion that is rahmatan lil alamin. To provide greater benefits to the wider community. UIN Malang provides Islamic values in all aspects of education that is carried out, so that later alumni can ground Islamic teachings around the world.

After clear segments and targets, UIN Malang made a clear and appropriate positioning. Positioning itself is more directed at establishing a vision, mission, goals, tagline, university promises that become the image of 
the campus and be remembered in the minds of stakeholders [18]. So far, the most remembered positioning by stakeholders is UIN Malang as a bilingual campus, a tahfidz campus, a campus that integrates Islam and science as well as universities and ma'had. In 2019, UIN Malang carried out a vision and mission renewal, but it still has the same values as the previous vision and mission.

Positioning of UIN Malang is supported by differentiation, namely different offerings in the form of programs, activities or learning to support the built positioning. Positioning as a bilingual campus, for example, is supported by a language center. Which offers two language programs that are compulsory for all students. The Arabic language program which is commonly referred to as PKPBA (Special Program for Arabic Language Classes) is held in semester 1 and 2, for two full semesters, from Monday to Friday. English is given by the name of the PKPBI program (Special Program for English Language Classes) and is given in semesters 3 and 4 .

As for positioning as a scientific integration campus, Prof. Imam Suprayogo, the rector of UIN Malang in 2004-2012 made a tree of knowledge, which became a model for the development of scientific integration on campus. In addition, an Integration Unit was also held. Which discusses and discusses the themes of scientific integration. As for the integration between higher education and religion, UIN Malang has a differentiation in the form of the Ma'had al-Jami'ah Center. All students in the first year are required to live in the ma'had and take part in the ma'had program, which includes habituation of worship, ta'lim al-Quran, ta'lim Afkar, Arabic and English language learning. Habitual rituals of worship, starting to purify, pray, fasting sunnah, speaking in Arabic and English, and other programs.

The unity of this positioning and differentiation has finally formed the UIN Malang brand. Which is then promoted and introduced to the target segment. Through several activities held by public relations, student affairs, academics, and so on. Increasing the quality and quantity of programs is also continuously carried out, in which there is also a quality study institution that oversees the programs carried out to comply with the quality standards set by the university.

\subsection{Branding Strategy of UIN Maulana Malik Ibrahim Malang during the Pandemic}

If before the pandemic, each university focused on the positioning and differentiation of each, then during the pandemic, all campuses were required to play and compete on the same focus, namely e-learning. Online learning is an important thing that must be done, packaged, and presented in an elegant way, while still prioritizing learning content, understanding students, and teaching the latest technology to all lecturers, especially senior professors who are very qualified in science, but often lag behind in use of the internet, learning technology and online media.

Universities are required to maintain the brand that has been built, communicate to stakeholders virtually, and enter the gaps needed by stakeholders and potential stakeholders. During the pandemic, universities have changed a lot in managing their campuses and campus brands. Both internally and externally. As for UIN Maulana Malik Ibrahim Malang, views the Covid-19 pandemic itself from two sides, challenges and opportunities.

\subsubsection{Challenges during a pandemic}

The challenges faced include the rapid adaptation of offline learning to online. This requires tremendous cost, time, and effort to provide training, design systems, and continue to improve the quality of online lectures [19]. Future plans, making learning videos can be facilitated by the campus, so that lecturers can be more creative in making learning media.

Other challenges faced during Covid-19 are administrative services, ma'had programs and language programs that must adapt quickly too. The ma'had program itself provides ta'lim al-Quran and Afkar online. But the experience of student participation in providing the values instilled by the university is difficult to apply. There are 4 aspects of campus values, namely spiritual depth, moral excellence, breadth of knowledge and professional maturity. For the first and second grades, all students should take part in the activities directly on campus and ma'had. The third and fourth grades can be done online.

The brand experience that should be experienced by students themselves during college with socialization and experiencing the brand value built on campus and it has not yet been realized, but the better digital quality is expected to provide solutions, on how the curriculum is designed, packaged and presented is a challenge must be faced by all campuses, including UIN Malang.

\subsubsection{Opportunities during a pandemic}

Apart from the challenges faced, UIN Malang also saw the opportunities that emerged during the pandemic. For example, the emergence of the fintech industry, in response to the increasingly dominating digitalization of learning. More and more campus investment is directed at the digital aspect. This is a new breakthrough, a major change that has seemed difficult to implement, but with the pandemic requiring distance learning, making online learning the best solution must be done immediately. 
The revolution in education has been long awaited, seeing the digitization of all aspects of life, especially the millennial generation. Starting to change the education system and making education digitization is not easy. But with the pandemic slowly everything goes, changes, adapts, and makes this revolution happen. Likewise, UIN Malang, the idea of conducting elearning learning, was realized more optimally during the pandemic.

Another hope in managing brands during a pandemic is to strengthen brand identity and brand image. The brand identity is strengthened by strengthening the university's brand identity, with various new breakthroughs needed by stakeholders and in accordance with the university's values. The brand image is strengthened by communicating the university's brand through various methods and media. Online media has become a very effective means of communicating the university brand.

The segmentation and targetting of universities during pandemic times could be wider, because learning is more accessible. How to register, select, learn, and several things in lectures are more easily accessible. This is also an opportunity for the university to expand its target market.

Most important thing that must be held in managing a brand during a pandemic, is to persist in the positioning that has been built, strive to consistently uphold the values that are believed to be, strengthen differentiation to achieve positioning adjusted to conditions during the pandemic, and communicate the university's values to stakeholders well.

\section{CONCLUSION}

The branding strategy of UIN Malang before the pandemic was carried out by establishing a positioning, namely the university's promises to stakeholders, in the form of a vision, mission, goals and university slogans. Then it is strengthened by differentiation, namely the differentiating advantages that are owned to support positioning, either in the form of activities, programs or curriculum design. These two entities between postioning and differentiation are tailored to the specified market segments, whether local, national, regional or international levels. Positioning and differentiation that have been built optimally are then communicated and promoted properly to stakeholders.

The branding strategy during the pandemic was carried out by strengthening the university's positioning, coupled with differentiation in the digital field. Facilitate all services to stakeholders, organize and present lectures creatively, provide added value that can support university values and campus positioning. Then communicate to stakeholders using digital, creatively and attractively.

\section{REFERENCES}

[1] A. M. Sadat, Brand belief: Strategi Membangun Merek Berbasis Keyakinan, Jakarta: Salemba Empat, 2009.

[2] T. Paul and K. C. Lee, Hi-Tech Hi-Touch Branding, Jakarta: Salemba Empat, 2002.

[3] C. Sohrabi et al., "World Health Organization Declares Global Emergency: a Review of the 2019 Novel Coronavirus (COVID-19)", Int. J. Surg., 76 (2020) 71-76, DOI: 10.1016/j.ijsu.2020.02.034

[4] N. Hollis, the Global Brand: How to Create and Develop Lasting Brand Value in the World Market, Macmillan, 2008.

[5] F. Tjiptono, Brand Management \& Strategy, Yogyakarta: Andi, 2005.

[6] P. Kotler, Marketing for Competitiveness. Bentang Pustaka, 2017.

[7] S. Sholikah, "Branding Institusi Perguruan Tinggi Keagamaan Islam Swasta Di Kawasan Pesisir (Studi Multi Situs Di STITMA Tuban Dan IAI Tabah Kranji Paciran Lamongan)," Al Hikmah J. Stud. Keislam, 8(2) (2018) 184-196.

[8] H. Kartajaya, Marketing Plus 2000: Siasat Memenangkan Persaingan Global, Jakarta: PT, Gramedia Pustaka Utama, 2000.

[9] P. Kotler and L. K. Keller, Manajeman Pemasaran (Penerjemah: Benyamin), 2009.

[10] H. Kartajaya, Positioning, Diferensiasi dan Brand, Jakarta: Gramedia Pustaka Utama, 2004.

[11] M. de Swaan Arons and F. van den Driest, The Global Brand Ceo: Building the Ultimate Marketing Machine in Airstream International, 2010.

[12] D. A. Aaker, Building Strong Brands The Free Press, New York, 1996.

[13] D. Oetomo, Penelitian Kualitatif: Aliran dan Tema, Metod. Penelit. Sos. Berbagai Altern. Pendekatan, Jakarta: Kencana, 2007.

[14] J. W. Creswell and C. N. Poth, Qualitative inquiry and research design: Choosing among five approachesm Sage publications, 2016.

[15] Sugiyono, Metode Penelitian Kuantitatif Kualitatif dan R\&D, Bandung, 2017.

[16] N. Zuriah, Metodologi Penelitian Sosial Dan Pendidikan: Teori, Aplikasi. Jakarta: Bumi Aksara, 2006.

[17] M. Fajar, Proses Perubahan STAIN menjadi UIN 
Malang, Malang: UIN Malang Press, 2004.

[18] M. Marrs, R. Gajos, and M. Pinar, Utilizing Brand Audit to Develop a University Brand: A Case Study, in ASBBS Annual Conference, 964-975, 2011.
[19] N. Fattah and B. P. Gautama, Penerapan Biaya Pendidikan Berbasis Activity-Based Costing dalam Meningkatkan Mutu Pendidikan di Perguruan Tinggi: Studi Kasus di Universitas Pendidikan Indonesia, Mimb. Pendidik., 2,(1) (2017) 19-32. DOI: https://doi.org/10.2121/mp.v2i1.791.g754 